\title{
TRYPANOSOMATIDS IN DOGS BELONGING TO INDIVIDUALS WITH CHRONIC CHAGAS' DISEASE LIVING IN BOTUCATU TOWN AND SURROUNDING REGION, SÃO PAULO STATE, BRAZIL
}

LUCHEIS S. B. (1), DA SILVA A. V. (2), ARAÚJO JR J. P. (3), LANGONI H. (4), MEIRA D. A. (1), MARCONDES-MACHADO J. (1)

(1) Laboratory of Tropical Diseases, Botucatu School of Medicine, São Paulo State University, UNESP, Botucatu, São Paulo, Brazil; (2) Paraná State University, UNIPAR, Umuarama, Paraná, Brazil; (3) Institute of Biosciences, São Paulo State University, UNESP, Botucatu, São Paulo, Brazil; (4) Laboratory of Zoonoses Diagnostic, Botucatu School of Veterinary Medicine and Animal Husbandry, São Paulo State University, UNESP, Botucatu, São Paulo, Brazil.

ABSTRACT: Among domestic animals, dogs are considered to be the major reservoirs of trypanosomatids and, due to their proximity to man, the presence of these parasites in dogs is an alert to actions aiming at triatomine control. Fifty dogs (26 males and 24 females), aged from 2 months to 15 years, belonging to 30 chronic Chagas' disease individuals from 15 different municipalities in the western region of São Paulo State, Brazil, were subjected to blood collection for the following tests: artificial xenodiagnosis, blood culture, and Polymerase Chain Reaction (PCR). Fortythree (86\%) out of 50 dogs were positive to at least one of the tests performed; 34 (68\%) were positive to xenodiagnosis, $30(60 \%)$ to blood culture, and $25(50 \%)$ to PCR for T. cruzi and/or T. rangeli. Although triatomines were not detected during the intra and peridomiciliary inspections in the dog owners' residences, the results obtained demonstrate that there is a transmission cycle whereby triatomine vector may be participating in the infection epidemiological chain.

KEY WORDS: Trypanosoma cruzi, T. rangeli, dog, xenodiagnosis, blood culture, polymerase chain reaction.

\section{CORRESPONDENCE TO:}

SIMONE BALDINI LUCHEIS, Rodovia Marechal Rondon, Km 279 , Caixa Postal 108, 18650-970, São Manuel, São Paulo, Brazil, Email: silucheis@bol.com.br 
S. B. Lucheis et al TRYPANOSOMATIDS IN DOGS BELONGING TO INDIVIDUALS WITH CHRONIC CHAGA'S DISEASE LIVING IN BOTUCATU TOWN AND SURROUNDING REGION, SÃO PAULO STATE, BRAZIL. J. Venom. Anim. Toxins incl. Trop. Dis., 2005, 11, 4, p. 493

\section{INTRODUCTION}

Trypanosomiases, mainly induced by the flagellate protozoa Trypanosoma cruzi (8) and $T$. rangeli (26), represent important infections for both humans and animals. $T$. cruzi, when transmitted by bloodsucking triatomine insects (Hemíptera: Reduviidae), causes Chagas' disease, one of the major endemic zoonoses in the American Continent, where 16 to 18 million infected individuals are expected to exist (31). Among the main domestic mammals that are reservoirs of trypanosomatids, dogs are actually behaving as natural sentinels in surveillance areas where campaigns for vector controls have been held (7). They are also common victims and develop pathological changes similar to those detected in humans $(1,16)$.

In the state of São Paulo, Brazil, in the early eighties, as a result of measures adopted against triatomine vector, Triatoma infestans was virtually eliminated. Since then, little is known about reservoir animals and trypanosome population that might be circulating. This is true especially for municipalities of the western region of the state, with an important history of Chagas' disease and where many individuals were chronically infected by $T$. cruzi.

The objective of the present paper was to study dogs belonging to chronic Chagas' disease individuals from municipalities of the western region of São Paulo State, to investigate the role of these animals as reservoirs of trypanosomatids of public health interest such as $T$. cruzi and $T$. rangeli.

\section{MATERIALS AND METHODS}

\section{Areas surveyed}

Thirteen municipalities of the western region of São Paulo State, Brazil, were visited from February to September 2001 (Figure 1).

\section{Dog owners characteristics}

The study included 30 individuals with chronic Chagas' disease, routinely examined at the Outpatient Clinic for Parenteral Transmission Diseases of Botucatu School of Medicine, UNESP, and that lived in Botucatu and surrounding regions, São Paulo State, Brazil. 
S. B. Lucheis et al TRYPANOSOMATIDS IN DOGS BELONGING TO INDIVIDUALS WITH CHRONIC CHAGA'S DISEASE LIVING IN BOTUCATU TOWN AND SURROUNDING REGION, SÃO PAULO STATE, BRAZIL. J. Venom. Anim. Toxins incl. Trop. Dis., 2005, 11, 4, p. 494

\section{Dogs characteristics}

The 50 animals studied (26 males and 24 females) belonged to 30 chronic chagasic individuals. All the dogs were living with their owners, and most of them presented a good general aspect. The animals ranged in age from 2 months to 15 years; 41 were mongrels (24 from the urban zone and 17 from the rural zone), and nine were of defined race and from the urban zone.

\section{Sample collection}

Blood samples $(8 \mathrm{ml})$ were collected from the brachiocephalic and saphena veins of each of the dogs in their homes for artificial xenodiagnosis, blood culture, and Polymerase Chain Reaction (PCR).

\section{Survey of Triatomines in the domiciles}

On the occasion of visits to each domicile for dogs' blood collection, the intra and peridomicile were surveyed for the presence of triatomines (nymphs and/or adults) or their signs by trained government employees, with special emphasis on the sites of greater permanence of the dogs (Figure 2).

\section{Artificial Xenodiagnosis}

We used $5 \mathrm{ml}$ of each blood sample for artificial xenodiagnosis, which involved 40 first-instar nymphs of the vector Dipetalogaster maximus, a species of Mexican origin, maintained in the Laboratory of Tropical Diseases of the School of Medicine of Botucatu, UNESP. Thirty days after feeding on the animal's blood samples, all insects were examined by the abdominal compression method and the feces were prepared with buffered saline solution (PBS, $\mathrm{pH}$ 7.2) and observed under light microscope at $250 \mathrm{X}$ to $400 \mathrm{X}$ magnification (6)

\section{Blood culture}

Plasma, leukocyte layer, and red blood cell sediment were obtained from $3 \mathrm{ml}$ whole blood without centrifugation and cultured on sterile liver infusion tryptose (LIT) medium. The tubes were then incubated in an oven at $28-30^{\circ} \mathrm{C}$ and daily homogenized. Readings of the tubes were performed every two weeks by removing under a laminar flow hood a 5- $\mu$ l aliquot, which was examined at $1000 \mathrm{X}$ 
S. B. Lucheis et al TRYPANOSOMATIDS IN DOGS BELONGING TO INDIVIDUALS WITH CHRONIC CHAGA'S DISEASE LIVING IN BOTUCATU TOWN AND SURROUNDING REGION, SÃO PAULO STATE, BRAZIL. J. Venom. Anim. Toxins incl. Trop. Dis., 2005, 11, 4, p. 495

magnification. The tubes were kept up to 120 days and, even when negative, were processed for PCR. Positive samples were monthly replated to a new tube containing sterile LIT medium and kept at $28-30^{\circ} \mathrm{C}$ until PCR.

\section{Preparation of canine blood samples in LIT medium for the PCR technique}

The trypanosomes isolated by blood culture and kept in LIT medium at $28-30^{\circ} \mathrm{C}$ as well as negative cultures were washed in sterile PBS, $\mathrm{pH} 7.2$, and centrifuged twice at $1000 \mathrm{rpm}$ for $10 \mathrm{~min}$. The sediments obtained were stored in microtubes at $-20^{\circ} \mathrm{C}$ until DNA extraction (19).

\section{DNA extraction}

A 250- $\mu$ l aliquot of each blood sample in LIT medium was added to $250 \mu$ of extraction buffer according to the extraction protocol described by Da Silva and Langoni (9). Two aliquots of the aqueous phase, $300 \mu \mathrm{l}$ and $200 \mu \mathrm{l}$, were removed from each sample and extracted once with a phenol:chloroform:isomylic alcohol solution (25:24:1) prior to precipitation with sodium acetate and ethanol. Each pellet obtained after centrifugation was resuspended in $50 \mu \mathrm{l}$ ultrapure water. The DNA extracted from the samples was not quantified.

\section{PCR conditions}

The P35 and P36 primers (25) were used for amplification of the kDNA minicircle fragments. In this reaction, the resulting products present are 330 base pairs (bp) long, corresponding to the amplification of the fragment containing a specific region of the kDNA minicircle of $T$. cruzi, (28), which may also anneal and amplify with kDNA minicircles of $T$. rangeli. The $Y$ strain of $T$. cruzi, kindly provided by the Institute of Tropical Medicine of São Paulo, was used as a positive control of the reaction, while TNE (Tris-NaCl-EDTA) and the control MIX of PCR were used as negative controls. Five $\mu$ samples of $100 \mathrm{bp}$ of DNA ladder were used as molecular weight standards. The amplifications were performed in a total volume of $50 \mu$ containing 5 $\mu \mathrm{l}$ PCR buffer (50 mmol KCl, $10 \mathrm{mmol}$ Tris- $\mathrm{HCl}$ ), $1.5 \mu \mathrm{MgCl}_{2}(1.5 \mathrm{mmol}), 8.0 \mu \mathrm{l}$ dNTP solution (1.25 mmol), $0.3 \cup$ Taq-polymerase, 10 pmol of P35 primer (5'AAATAATGTACGgGgGAGATGCATGA-3'), $10 \mu \mathrm{l}$ of P36 primer (5'GGGTTCGATTGGGGTTGGTGT-3'), $10 \mu$ of the extraction product of each sample, 
S. B. Lucheis et al TRYPANOSOMATIDS IN DOGS BELONGING TO INDIVIDUALS WITH CHRONIC CHAGA'S DISEASE LIVING IN BOTUCATU TOWN AND SURROUNDING REGION, SÃO PAULO STATE, BRAZIL. J. Venom. Anim. Toxins incl. Trop. Dis., 2005, 11, 4, p. 496

and $15.2 \mu \mathrm{l}$ of ultrapure water. All reagents used were from Invitrogen ${ }^{\circledR}$. PCR was started in a thermocycler (M. J. Research PTC-200) under the following conditions: 1 cycle at $96^{\circ} \mathrm{C}$ for $2 \mathrm{~min}$, denaturation, primer annexation and lengthening in 30 cycles for $1 \mathrm{~min}$ each at 94,60 , and $72^{\circ} \mathrm{C}$ for $10 \mathrm{~min}$ (3). The reaction products were subjected to $2.5 \%$ agarose gel electrophoresis in 0.5X Tris-borate-EDTA buffer (TBE) and the gel was stained with ethidium bromide for one hour (Figure 3).

\section{Statistical analysis}

The following two aspects were considered: influence of the patient characteristics (sex, age range, and origin) on the test results; comparison of the positivity proportions by the $\chi^{2}$ test, with calculation of $\kappa, z$ and $p$, where $z$ is the standard normal factor. The significance level was set at $p<0.05$ in all analyses (22).

\section{RESULTS}

Forty-three out of the 50 dogs (86\%) were positive to at least one of the three performed tests when considered as a whole (xenodiagnosis and/or blood culture and/or PCR). Twenty-three were male and 20 were female, with no statistical difference related to sex (Fisher: $p>0.10$ ) (Table 1).

Blood culture positivity was higher among males $\left(\chi^{2}=6.461 ; p<0.05\right)$ (Table 2$)$. No age range effect $\left(\chi^{2}=0.293 ; p>0.50\right)$ was observed on this result.

No sex, age range or origin effect was found in the xenodiagnosis $\left(\chi^{2}=0.642 ; p>0.50\right.$; $\left.\chi^{2}=0.476 ; p>0.50 ; \chi^{2}=0.848 ; p>0.10\right)$ or PCR results $\left(\chi^{2}=0.321 ; p>0.50 ; \chi^{2}=2.632 ;\right.$ $\left.\mathrm{p}>0.10 ; \chi^{2}=0.802 ; \mathrm{p}>0.10\right)$.

Forty-three dogs (86\%) tested positive to one or more of the three diagnostic tests, with the following age range distribution: 10 (83.3\%) out of the 12 dogs in age range I (from 0 months to 2 years), 17 (89.4\%) out of the 19 dogs in age range II (from 2 to 4 years), and $16(84.2 \%)$ out of the 19 dogs in age range III (older than 4 years) (Table 3).

Thirty (90.9\%) out of the 33 dogs from the urban zone and 13 (76.4\%) out of the 17 dogs from rural areas were positive to xenodiagnosis and/or blood culture and/or PCR. No significant correlation was detected between origin and positivity to xenodiagnosis and/or blood culture and/or PCR (Table 4). 
S. B. Lucheis et al TRYPANOSOMATIDS IN DOGS BELONGING TO INDIVIDUALS WITH CHRONIC CHAGA'S DISEASE LIVING IN BOTUCATU TOWN AND SURROUNDING REGION, SÃO PAULO STATE, BRAZIL. J. Venom. Anim. Toxins incl. Trop. Dis., 2005, 11, 4, p. 497

With respect to the concordance or reproducibility between pairs of techniques, 24 dogs were positive to both xenodiagnosis and blood culture and 10 were negative to both tests, with a concordance rate of $68 \%(\kappa=0.3103 ; \Delta \kappa=0.1393 ; z=2.23 ; p<0.05)$. Although significant, the concordance between the two methods was weak.

Twenty-one dogs were positive to both xenodiagnosis and PCR and 12 were negative to both tests, with a concordance rate of $66 \%(\kappa=0.32 ; \Delta \kappa=0.1319 ; z=2.43$; $\mathrm{p}<0.05)$. The concordance between the two methods, although significant, was weak. Eighteen dogs were positive to both blood culture and PCR and 13 were negative to both tests, with a concordance rate of $62 \%(\kappa=0.24 ; \Delta \kappa=0.1386 ; z=1.73 ; p>0.10)$.

Twenty-two dogs were positive to xenodiagnosis, blood culture and PCR and seven were negative to all the three tests, with a concordance rate of $58 \% \quad(\kappa=0.16$; $\Delta \kappa=0.1131 ; z=1.41 ; p>0.10)$ (Table 5).

The weak concordance or reproducibility between xenodiagnosis and/or blood culture and PCR was expected since xenodiagnosis and blood culture have the ability to detect any trypanosomatid, in contrast to PCR, since specific primers for $T$. cruzi and $T$. rangeli were used in the present study.

Eighteen (36\%) out of the 50 dogs were positive to xenodiagnosis and/or blood culture but negative to PCR, which exclusively detected T. cruzi and/or T. rangeli, indicating the presence of infection by trypanosomatids other than $T$. cruzi or $T$. rangeli (Table 5).

The search for vectors inside or around the domiciles visited did not detect any triatomines in these areas. 
S. B. Lucheis et al TRYPANOSOMATIDS IN DOGS BELONGING TO INDIVIDUALS WITH CHRONIC CHAGA'S DISEASE LIVING IN BOTUCATU TOWN AND SURROUNDING REGION, SÃO PAULO STATE, BRAZIL. J. Venom. Anim. Toxins incl. Trop. Dis., 2005, 11, 4, p. 498

Table 1: Influence of sex of 50 dogs living in the residence of patients with the chronic form of Chagas' disease examined at the Outpatient Clinic for Diseases of Parenteral Transmission, UNESP, on the occurrence of positivity to xenodiagnosis and/or blood culture and/or PCR.

\begin{tabular}{cccc}
\hline \hline \multicolumn{3}{c}{ Xenodiagnosis/Blood culture/PCR } \\
SEX & $\begin{array}{c}\text { Number of positive } \\
\text { dogs }\end{array}$ & Proportion & TOTAL \\
\hline Male & 23 & 0.8846 & 26 \\
Female & 20 & 0.8333 & 24 \\
TOTAL & 43 & 0.8600 & 50 \\
\hline \hline
\end{tabular}

Statistics: $\mathrm{p}>0.10$ (Fisher)

Note: No significant association between sex and a positive result of xenodiagnosis and/or blood culture and/or PCR was observed.

Table 2: Influence of sex of 50 dogs living in the residence of patients with the chronic form of Chagas' disease examined at the Outpatient Clinic for Diseases of Parenteral Transmission, UNESP, on the occurrence of positivity to blood culture.

\begin{tabular}{cccc}
\hline \hline SEX & $\begin{array}{c}\text { Number of positive } \\
\text { dogs }\end{array}$ & Proportion & TOTAL \\
\hline Male & 20 & 0.7692 & 26 \\
Female & 10 & 0.4167 & 24 \\
TOTAL & 30 & 0.6000 & 50 \\
\hline \hline
\end{tabular}

Statistics: $\chi^{2}=6.461 ; p<0.05$

Note: There was a significant correlation between sex and the result of blood culture, with a significantly higher positivity among males. 
S. B. Lucheis et al TRYPANOSOMATIDS IN DOGS BELONGING TO INDIVIDUALS WITH CHRONIC CHAGA'S DISEASE LIVING IN BOTUCATU TOWN AND SURROUNDING REGION, SÃO PAULO STATE, BRAZIL. J. Venom. Anim. Toxins incl. Trop. Dis., 2005, 11, 4, p. 499

Table 3: Influence of age range of 50 dogs living in the residence of patients with the chronic form of Chagas' disease examined at the Outpatient Clinic for Diseases of Parenteral Transmission, UNESP, on the occurrence of positivity to xenodiagnosis and/or blood culture and/or PCR.

\begin{tabular}{cccc}
\hline \hline & \multicolumn{2}{c}{ Xenodiagnosis/Blood culture/PCR } \\
AGE & Number of positive & Proportion & TOTAL \\
RANGE & dogs & 0.8333 & 12 \\
\hline I & 10 & 0.8947 & 19 \\
II & 17 & 0.8421 & 19 \\
TOTAL & 16 & 0.8600 & 50 \\
\hline \hline
\end{tabular}

I- dogs aged 0 months to 2 years; II - dogs aged 2 years to 4 years; III - dogs older than 4 years

Statistics: $\chi^{2}=0.312 ; p>0.50$

Note: There was no significant correlation between age range and positivity to xenodiagnosis and/or blood culture and/or PCR.

Table 4: Influence of origin, according to the residence zone, of 50 dogs living in the residence of patients with the chronic form of Chagas' disease examined at the Outpatient Clinic for Diseases of Parenteral Transmission, UNESP, on the occurrence of positivity to xenodiagnosis and/or blood culture and/or PCR.

\begin{tabular}{cccc}
\hline \hline & \multicolumn{3}{c}{ Xenodiagnosis/Blood culture/PCR } \\
ORIGIN & $\begin{array}{c}\text { Number of positive } \\
\text { dogs }\end{array}$ & Proportion & TOTAL \\
\hline Urban & 30 & 0.9091 & 33 \\
Rural & 13 & 0.7647 & 17 \\
TOTAL & 43 & 0.8600 & 50 \\
\hline \hline
\end{tabular}

\begin{tabular}{l}
\hline Statistics: $p>0.10$ (Fisher) \\
Note: There was no significant correlation between origin and positivity to \\
xenodiagnosis and/or blood culture and/or PCR.
\end{tabular}


S. B. Lucheis et al TRYPANOSOMATIDS IN DOGS BELONGING TO INDIVIDUALS WITH CHRONIC CHAGA'S DISEASE LIVING IN BOTUCATU TOWN AND SURROUNDING REGION, SÃO PAULO STATE, BRAZIL. J. Venom. Anim. Toxins incl. Trop. Dis., 2005, 11, 4, p. 500

Table 5: Agreement between the results obtained by xenodiagnosis and blood culture in relation to the results obtained by PCR for T. cruzi and/or T. rangeli for 50 dogs living in the residence of patients with the chronic form of Chagas' disease examined at the Outpatient Clinic for Diseases of Parenteral Transmission, UNESP.

\section{PCR}

\begin{tabular}{cccc}
$\begin{array}{c}\text { Xenodiagnosis/ } \\
\text { Blood culture }\end{array}$ & Positive & Negative & TOTAL \\
\hline Positive & 22 & 18 & 40 \\
Negative & 3 & 7 & 10 \\
TOTAL & 25 & 25 & 50 \\
\hline \hline
\end{tabular}

PCR: Polymerase chain reaction

Proportion of agreement: $p=29 / 50=0.58=58 \%$

Statistics: $\kappa=0.16 ; \triangle \kappa=0.1131 ; z=1.41 ; p>0.10$

Note: The agreement between the xenodiagnosis and blood culture tests in relation to PCR was very weak and non-significant.

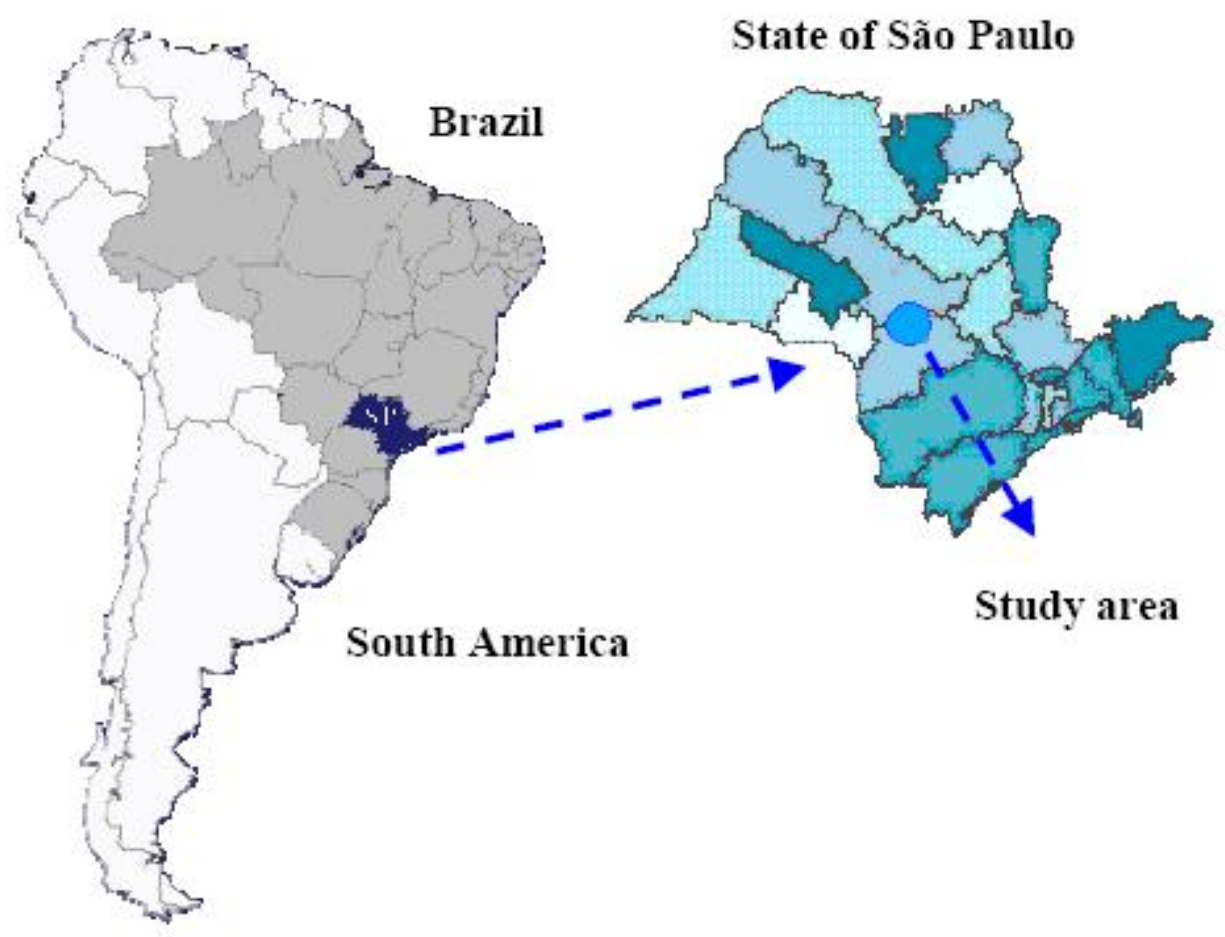

Figure 1: Maps showing the location of the studied area in the western region of São Paulo State, Brazil. 
S. B. Lucheis et al TRYPANOSOMATIDS IN DOGS BELONGING TO INDIVIDUALS WITH CHRONIC CHAGA'S DISEASE LIVING IN BOTUCATU TOWN AND SURROUNDING REGION, SÃO PAULO STATE, BRAZIL. J. Venom. Anim. Toxins incl. Trop. Dis., 2005, 11, 4, p. 501

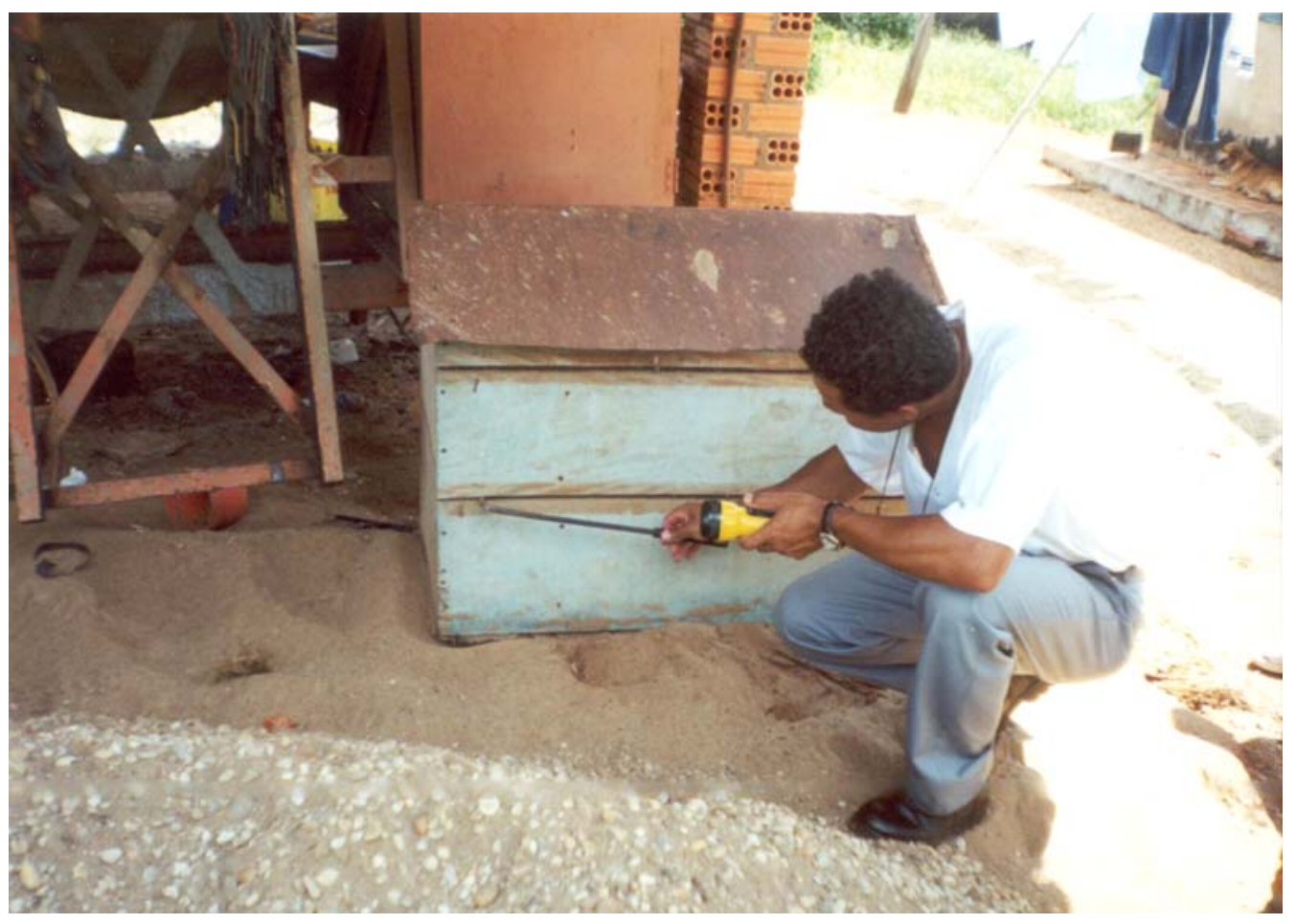

Figure 2: Government employee searching for triatomines during a visit to the peridomicile of a dog belonging to a patient with chronic Chagas' disease, in the studied area. 


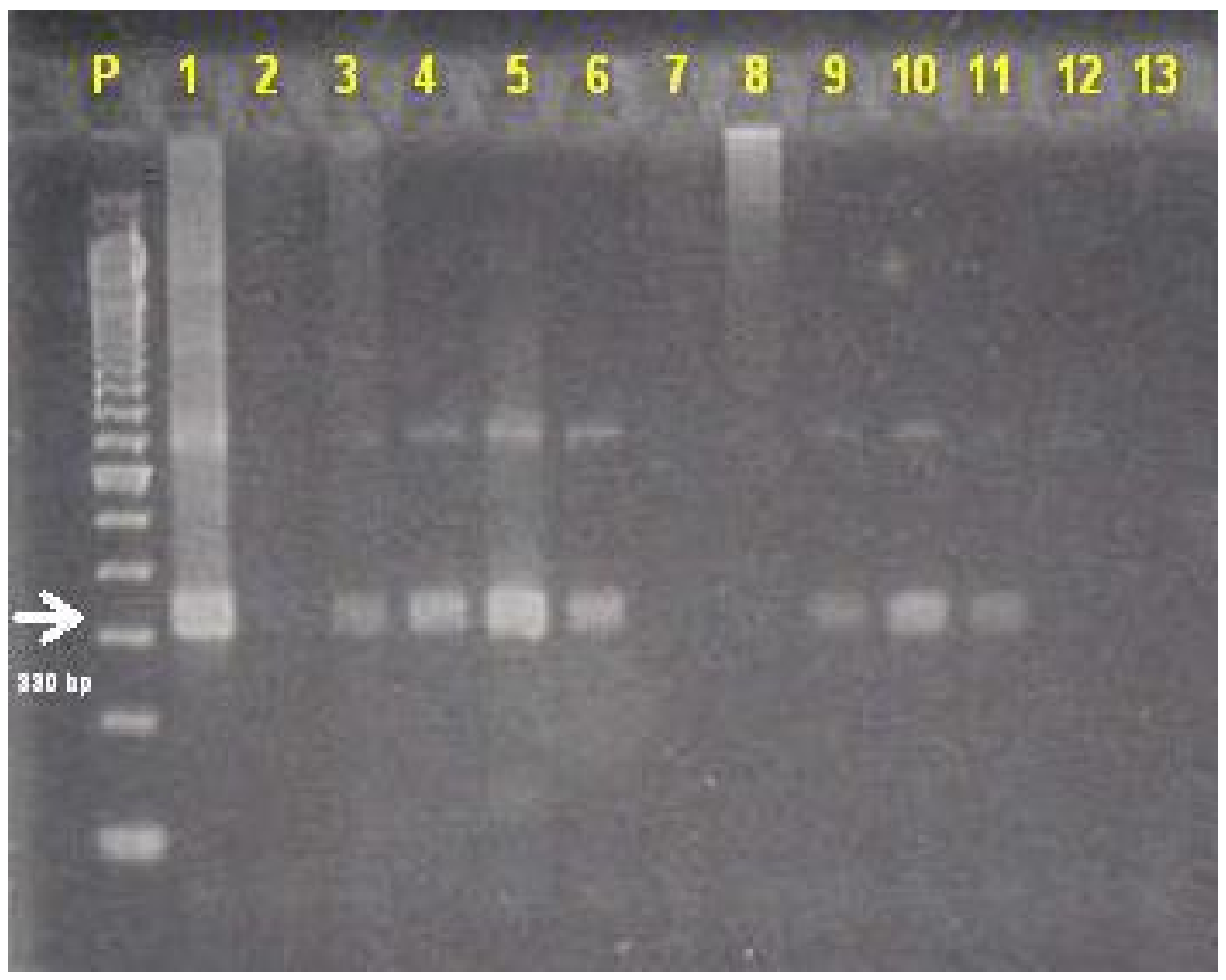

Figure 3: Results of the amplification of fragments of the kDNA minicircle of $T$. cruzi and/or $T$. rangeli by PCR, in ten blood samples of the 50 dogs studied, belonging to individuals with chronic Chagas' disease. Electrophoresis on $2.5 \%$ agarose gel stained with ethidium bromide showing the $330 \mathrm{bp}$ fragment derived from minicircles of T. cruzi and/or T. rangeli. P: Molecular weight standard (100 bp DNA ladder INVITROGEN ${ }^{\circledR}$ ); Line 1: positive control (T. cruzi Y strain); Line 12: negative control (Tris-NaCl-EDTA - TNE); Line 13: negative control (MIX - PCR); Lines 3, 4, 5, 6, 9, 10, and 11: positive samples for $T$. cruzi and/or $T$. rangeli; Lines 2, 7, and 8: negative samples.

\section{DISCUSSION}

The frequency of trypanosomatids infection among the dogs PCR positive for T. cruzi and/or $T$. rangeli may suggest that there may have been somehow an active transmission of these trypanosomatids to the dogs. It is possible that the dogs studied here were actually infected by triatomine vectors as were humans by contamination of abraded skin or conjunctiva with infected feces and urine of the vector insect, or even of the oral mucosa when the insect enters the mouth (37). However, in the absence of triatomines, as observed in the present study, we should 
S. B. Lucheis et al TRYPANOSOMATIDS IN DOGS BELONGING TO INDIVIDUALS WITH CHRONIC CHAGA'S DISEASE LIVING IN BOTUCATU TOWN AND SURROUNDING REGION, SÃO PAULO STATE, BRAZIL. J. Venom. Anim. Toxins incl. Trop. Dis., 2005, 11, 4, p. 503

still consider the possibility of trypanosomatid transmission by rodents and other wild animals such as opossums, which get increasingly closer to the peridomicile and/or domicile in search for shelter and food, mainly due to ecologic disequilibrium $(4,5$, $23,24)$. Thus, in the present study we observed that dogs from the urban zone had higher rates of infection than dogs from the rural zone, as determined by blood culture and PCR. These results may suggest that the circulation of trypanosomatids is increasingly closer to urban centers.

Although the vector was not detected in the domiciles visited, the probability of finding some triatomines in the regions studied cannot be ruled out. Actually, despite the success in the control of $T$. infestans in Brazil, Chile, and Uruguay (12, 32-36), there should be continuous vigilance about its presence, as it was shown by the detection of $109 \mathrm{~T}$. infestans specimens at focal points in peridomiciliary constructions on a farm located in Paulinea, São Paulo State, Brazil. The risk of occupation of the areas submitted to control action by wild species of triatomines still exists, possibly leading to important changes in the epidemiology of Chagas' disease (10). With the deactivation of the Program for the Control of Chagas' Disease in Brazil starting in the mid-eighties, the prophylactic actions have become less effective, with a consequent concrete possibility of intradomiciliation of triatomines (21).

In Brazil, both $T$. cruzi and $T$. rangeli were detected naturally infecting dogs and marsupials, respectively $(18,20,24)$. The simultaneous presence of $T$. rangeli and $T$. cruzi in the same geographic region permits the occurrence of single or mixed infections both in vertebrate and invertebrate hosts (17), impairing differential diagnosis of infection with the two species. Specific differentiation between $T$. cruzi and $T$. rangeli is of great practical importance since, although $T$. rangeli is not pathogenic to vertebrate hosts, when infecting humans it induces an immune response with cross-reactivity with $T$. cruzi, representing a barrier to the serologic diagnosis of human Chagas' disease in areas where these parasites coexist (13).

The P35 and P36 primers used for PCR in the present study were originally designed for amplification of the kDNA minicircle of $T$. cruzi (25) and have been used for the assessment of etiologic treatment of Chagas' disease in countries such as Bolivia or in areas of Brazil where the presence of $T$. rangeli has not yet been reported in humans (27). However, the use of these primers in countries where mixed infections 
S. B. Lucheis et al TRYPANOSOMATIDS IN DOGS BELONGING TO INDIVIDUALS WITH CHRONIC CHAGA'S DISEASE LIVING IN BOTUCATU TOWN AND SURROUNDING REGION, SÃO PAULO STATE, BRAZIL. J. Venom. Anim. Toxins incl. Trop. Dis., 2005, 11, 4, p. 504

with $T$. cruzi and $T$. rangeli are present in vectors and in vertebrate hosts may complicate the diagnosis. The amplification profile obtained in mixed infections depends on the proportion of parasites present in the blood sample or in the intestinal content of the vector, and the detection of the amplification profile for a trypanosome species may mask the presence of another species $(28,29)$. The 330 bp fragment of $T$. rangeli and the proximity of these two sets of fragments on the agarose gel used in the present study may have created difficulties for a specific diagnosis in mixed infections, since the detection of typical $T$. rangeli bands may not permit the visualization of an infection coexisting with T. cruzi (28).

With respect to blood culture, the use of LIT medium at $26-28^{\circ} \mathrm{C}$ favors the development not only of $T$. cruzi but also of all trypanosomes whose development ends in the posterior portion of the vector (15), as in the case of T. rangeli. In the present study, blood culture proved to be a good diagnostic method, with $60 \%$ sample positivity, in agreement with Barbosa et al. (4), who obtained $20 \%$ to $60 \%$ positivity in blood cultures with or without previous blood centrifugation. Similarly, Fernandes et al. (11) obtained $53 \%$ positivity and observed that reduced manipulation of the blood samples increased the positivity of blood culture. Those results agree with the method good performance in this study, in which blood centrifugation was not performed either, but as it was observed for xenodiagnosis, blood culture is also a limited method for the precise distinction between T. cruzi and $T$. rangeli simply by direct observation under microscope, since these species can even be confused with other trypanosomatids.

Although trypanosomatids were detected by xenodiagnosis in $68 \%$ of the dogs studied and, by blood culture, in 60\%, the agreement between the results obtained with the two methods, although significant, was weak or marginal. Similarly, the agreement between xenodiagnosis and PCR, although significant, was weak or marginal. These results may be due to the difference in the sensitivity levels of the diagnostic techniques used, leading to different results even when the techniques are performed by the same person and all the procedures inherent to the various laboratory techniques are observed. In addition, since only specific primers for $T$. cruzi and $T$. rangeli were used, the lack of agreement between xenodiagnosis and blood culture and PCR was expected. 
S. B. Lucheis et al TRYPANOSOMATIDS IN DOGS BELONGING TO INDIVIDUALS WITH CHRONIC CHAGA'S DISEASE LIVING IN BOTUCATU TOWN AND SURROUNDING REGION, SÃO PAULO STATE, BRAZIL. J. Venom. Anim. Toxins incl. Trop. Dis., 2005, 11, 4, p. 505

In an experimental study, Araujo et al. (2) detected positivity to PCR in $100 \%$ of dogs infected with T. cruzi after 5 to 12 years. For dogs with infection lasting more than 10 years, many repetitions of PCR and a larger number of procedures for DNA extraction were needed. The need to repeat PCR procedures to insure a diagnosis of chronic T. cruzi infection indicates that this method, at present, should not be used and interpreted in a separate manner as a single and conclusive tool for the diagnosis of trypanosomiasis in dogs. In the present study, from the dogs with a negative PCR result but a positive xenodiagnosis and/or blood culture, corresponding to 18 of the 50 animals studied (36\%), only four were in age range III (more than 4 years old). This observation may indicate that, even if the dogs presented trypanosomatids other than T. cruzi or T. rangeli at that time, and if PCR had been repeated later using new samples, positivity for these species might have been detected not only in the animals in this age range, but also in the animals in age ranges I and II.

In the blood culture test, male dogs showed significantly higher positivity than females. Concerning occurrence of infections related to sex, Grossman (14) reported that the incidence and severity were higher in males, in agreement with a study by Williams et al. (30) reporting nine fatal cases of trypanosomiasis affecting dogs, eight of which were male.

\section{CONCLUSION}

The high frequency of trypanosomatids infection among dogs belonging to individuals with chronic Chagas' disease in this study could be pointing to a transmission cycle whereby the triatomine vector may be involved, although it was not detected in the domiciles visited. Maybe these results should be considered as an alert to the need of surveillance programs for Chagas' disease transmission in the studied area.

\section{ACKNOWLEDGMENTS}

We are most grateful to Superintendence for Control of Endemic Diseases (Superintendência de Controle de Endemias - SUCEN) of Botucatu, São Paulo State, Brazil; to Professor Vicente Amato Neto; and to Institute of Tropical Medicine of São Paulo, Brazil. 
S. B. Lucheis et al TRYPANOSOMATIDS IN DOGS BELONGING TO INDIVIDUALS WITH CHRONIC CHAGA'S DISEASE LIVING IN BOTUCATU TOWN AND SURROUNDING REGION, SÃO PAULO STATE, BRAZIL. J. Venom. Anim. Toxins incl. Trop. Dis., 2005, 11, 4, p. 506

\section{REFERENCES}

1 ANDRADE ZA., ANDRADE SG., SADIGURSKY M., WENTHOLD RJ., HILBERT JR., FERRANS VJ. The indeterminate phase of Chagas' disease: ultrastructural characterization of cardiac changes in the canine model. Am. J. Trop. Med. Hyg., 1997, 57, 328-36.

2 ARAÚJO FMG., BAHIA MT., MAGALHÃES NM., MARTINS-FILHO AO., VELOSO VM., CARNEIRO CM., TAFURI WL., LANA M. Follow-up of experimental chronic Chagas' disease in dogs: use of polymerase chain reaction (PCR) compared with parasitological and serological methods. Acta Trop., 2002, 81, 21-31.

3 ÁVILA HA., PEREIRA JB., THIEMANN O., DE PAIVA E., DI GRAVE W., MORE CM. Detection of Trypanosoma cruzi in blood specimens of chronic chagasic patients by polymerase chain reaction amplification of kinetoplast minicircle DNA: comparison with serology and xenodiagnosis. J. Clin. Microbiol., 1993, 31, 2421-6.

4 BARBOSA W., CZEREWUTA AC., OLIVEIRA RL. Tentativa de isolamento primário de Trypanosoma cruzi de pacientes crônicos de doença de Chagas por hemocultura - agentes bloqueadores. Rev. Pat. Trop., 1983, 12, 155-63.

5 BARRETO MP., RIBEIRO RD. Reservatórios silvestres do Trypanosoma (Schizotrypanum) cruzi (Chagas, 1909). Rev. Inst. Adolfo Lutz, 1979, 39, 2536.

6 BRUMPT E. Le xenodiagnostic. Application au diagnostic de quelques infections parasitaires et em particulier à la trypanosomose de Chagas. Bull. Soc. Pathol. Exot., 1914, 7, 706-10.

7 CASTAÑERA MB., LAURICELLA MA., CHUIT R., GURTLER RE. Evaluation of dogs as sentinels of the transmission of Trypanosoma cruzi in a rural area of north-western Argentina. Ann. Trop. Med. Parasitol., 1998, 92, 671-83.

8 CHAGAS C. Nova tripanozomíase humana. Estudos sob a morfologia e o ciclo evolutivo do Schizotrypanum cruzi n. gen., s. sp. Agente etiológico de nova entidade mórbida do homem. Mem. Inst. Oswaldo Cruz, 1909, 1, 159-218.

9 DA SILVA AV., LANGONI H. The detection of Toxoplasma gondii by comparing cytology, histopathology, bioassay in mice and the polymerase chain reaction (PCR). Vet. Parasitol., 2001, 97, 191-8. 
S. B. Lucheis et al TRYPANOSOMATIDS IN DOGS BELONGING TO INDIVIDUALS WITH CHRONIC CHAGA'S DISEASE LIVING IN BOTUCATU TOWN AND SURROUNDING REGION, SÃO PAULO STATE, BRAZIL. J. Venom. Anim. Toxins incl. Trop. Dis., 2005, 11, 4, p. 507

10 DUJARDIN JP. Population genetics and the natural history of domestication in triatominae. Mem. Inst. Oswaldo Cruz, 1998, 93, 34-6.

11 FERNANDES AJ., DIOTAIUTI L., AZEREDO BVM., BUSEK SU., CHIARI E. Viabilidade da utilização da hemocultura no diagnóstico da infecção pelo Trypanosoma cruzi em amostras coletadas em condições de campo. Rev. Soc. Bras. Med. Trop., 1995, 28, 123.

12 FUNDAÇÃO NACIONAL DE SAÚDE (FUNASA). FUNASA obtém certificação internacional para a Doença de Chagas. [cited 2000 Mar 23]. Available from: http://www.funasa.gov.br/not/not52.htm.

13 GRISARD EC., STEINDEL M., GUARNERI AA., EGER-MANGRICH I., CAMBPEL DA., ROMANHA AJ. Characterization of Trypanosoma rangeli strains isolated in Central and South America: an overview. Mem. Inst. Oswaldo Cruz, 1999, 94, 203-9.

14 GROSSMAN CJ. Immunoendocrinology. In: GREENSPAN FS. Ed. Basic and clinical endocrinology. London: Prentice-Hall, 1990: 40-52.

15 HOARE CA. Herpetosoma from man and other animals: Trypanosoma (herpetosoma) rangeli Tejera, 1920. In: The Trypanosomes of mammals: a zoological monograph. Oxford: Blackwell Scientific Publications, 1972: 288313.

16 MEURS KM., ANTHONY MA., SLATER M., MILLER MW. Chronic Trypanosoma cruzi infection in dogs: 11 cases (1987-1996). J. Am. Vet. Med. Assoc., 1998, 213, 497-500.

17 MILES MA., ARIAS JR., VALENTE SA., NAIFF RD., SOUZA AA., POVOA MM., LIMA JA., CEDILLOS RA. Vertebrate hosts and vectors of Trypanosoma rangeli in the Amazon basin of Brazil. Am. J. Trop. Med. Hyg., 1983, 32, 12519.

18 PÍFANO F., PEÑALVER LM., MEDINA R., DOMINGUEZ E. La infección natural del perro por el Trypanosoma rangeli. Primera comprobación de un reservorio vertebrado extra-humano de protozoario de la natureza. Gac. Med. Car, 1948, 56,7 . 
S. B. Lucheis et al TRYPANOSOMATIDS IN DOGS BELONGING TO INDIVIDUALS WITH CHRONIC CHAGA'S DISEASE LIVING IN BOTUCATU TOWN AND SURROUNDING REGION, SÃO PAULO STATE, BRAZIL. J. Venom. Anim. Toxins incl. Trop. Dis., 2005, 11, 4, p. 508

19 PINTO PLS. Circulação e caracterização de Trypanosoma cruzi isolados de mamíferos silvestres capturados no Estado de São Paulo - Brasil. São Paulo: Universidade de São Paulo, Faculdade de Saúde Pública, 2000. 141p. [Tese - Doutorado]

20 RAMIREZ LE., MACHADO MI., MAYWALD PG., MATOS A., CHIARI E., LAGESSILVA E. Primeira evidência de Trypanosoma rangeli no sudeste do Brasil, região endêmica para doença de Chagas. Rev. Soc. Bras. Med. Trop., 1998, 31, 99-102.

21 RAMOS Jr. NA., CARVALHO DM. Os diferentes significados da certificação conferida ao Brasil como estando livre da doença de Chagas. Cad. Saúde Públ., 2001, 17, 1403-12.

22 ROSNER B. Fundamental of biostatistics. 2.ed. Boston: Duxbury Press, 1986. 583p.

23 SHERLOCK IA. Epidemiology and dynamics of the vectorial transmission of Chagas disease. Mem. Inst. Oswaldo Cruz, 1999, 94, 385-6.

24 STEINDEL M., SCHOLZ AF., TOMA HK., SCHLEMPER Jr. BR. Presence of Trypanosoma cruzi in the anal glands of naturally infected opossum (Didelphis marsupialis) in the State of Santa Catarina, Brazil. Mem. Inst. Oswaldo Cruz, 1988, 93, 341-64.

25 STURM NR., DEGRAVE W., MOREL C., SIMPSON L. Sensitive detection and schizodeme classification of Trypanosoma cruzi cells by amplification of kinetoplast minicircle DNA sequences: use in diagnosis of Chagas' disease. Mol. Biochem. Parasitol., 1989, 33, 205-14.

26 TEJERA E. Un nouveau flagellé de Rhodnius prolixus, Trypanosoma (ou Crithidia) rangeli n. sp. Bull. Soc. Pathol. Exot., 1920, 13, 527.

27 VALLEJO GA., GUHL F., CARRANZA JC., LOZANO LE., SÁNCHEZ JL., JARAMILLO JC. DNA markers define two major Trypanosoma rangeli lineages in Latin-America. Acta Trop., 2002, 81, 77-82.

28 VALLEJO GA., GUHL F., CHIARI E., MACEDO AM. Species specific detection of Trypanosoma cruzi and Trypanosoma rangeli in vector and mammalian hosts by polymerase chain reaction amplification of kinetoplast minicircle DNA. Acta Trop., 1999, 72, 203-12. 
S. B. Lucheis et al TRYPANOSOMATIDS IN DOGS BELONGING TO INDIVIDUALS WITH CHRONIC CHAGA'S DISEASE LIVING IN BOTUCATU TOWN AND SURROUNDING REGION, SÃO PAULO STATE, BRAZIL. J. Venom. Anim. Toxins incl. Trop. Dis., 2005, 11, 4, p. 509

29 VARGAS N., SOUTO RP., CARRANZA JC., VALLEJO GA., ZINGALES B. Amplification of a specific repetitive DNA sequence for Trypanosoma rangeli identification and its potential application in epidemiological investigations. Exp. Parasitol., 2000, 96, 147-59.

30 WILLIAMS GD., ADAMS LG., YAGER RG., MC GRATH RK., READ WK., BILDERBACK WR. Naturally occurring trypanosomiasis (Chagas' disease) in dogs. J. Am. Vet. Med. Assoc., 1977, 171, 171-7.

31 WORLD HEALTH ORGANIZATION. Control of Chagas' disease. Report of a WHO Expert Committee. Geneva: World Health Organization, 1991. 1-95. (WHO Tech. Rep. Ser., 811)

32 WORLD HEALTH ORGANIZATION. Chagas disease, Uruguay - Interruption of transmission. Weekly Epidemiol. Rec., 1998, 73, 1-4.

33 WORLD HEALTH ORGANIZATION. Chile and Brazil to be certified free of transmission of Chagas disease. TDR News, 1999, 59, 10.

34 WORLD HEALTH ORGANIZATION. Chagas disease interrupted in Chile. TDR News, 2000a, 61, 10.

35 WORLD HEALTH ORGANIZATION. Brazil to be declared free of Chagas disease. TDR News, 2000b, 62, 14.

36 WORLD HEALTH ORGANIZATION. Chagas disease, Chile - Certification of interruption of transmission. Weekly Epidemiol. Rec., 2000c, 75, 10-12.

37 ZELEDÓN R., MONTENEGRO VM., ZELEDÓN O. Evidence of colonization of man-made ecotopes by Triatoma dimidiata (Latreille, 1811) in Costa Rica. Mem. Inst. Oswaldo Cruz, 2001, 96, 659-60. 